\title{
EFFECT OF CALCIUM CHLORIDE, SODIUM CHLORIDE AND LIME JUICE ON PHYSICO-CHEMICAL PROPERTIES OF CUCUMBER
}

\section{NAVEENA B \& GENITHA IMMANUEL}

Department of Agricultural Process and Food Engineering, SHUATS, Allahabad, Uttar Pradesh, India

\begin{tabular}{|l|}
\hline ABSTRACT \\
Post harvest losses of fruits and vegetables are a serious problem, because of the rapid deterioration during \\
handling, transport and storage in tropical regions. Cucumbers were treated with Calcium Chloride, Sodium Chloride \\
and Lime juice, with different steeping time. The effects of these chemicals and natural agents on pre-treated \\
cucumbers were evaluated, by analyzing the pH, TSS, Weight loss and Shelf life. The results indicated that, due to pre- \\
treatment increase in pH, TSS and Weight loss was lower, in cucumbers treated with Calcium Chloride and Sodium \\
Chloride as compared to Control, there was no significant difference between cucumbers, treated with Lime juice and \\
control. Shelf life of Cucumbers, treated with Calcium Chloride with a steeping time of 5 min was increased from 16 \\
days to 19 days; shelf life of Cucumbers with steeping time of 10 min was increased, from 16 days to 22 days. \\
KEYWORDS: pH, TSS, Calcium Chloride, Sodium Chloride \& Lime Juice
\end{tabular}

\section{INTRODUCTION}

Fruits and vegetables are a major source of essential dietary nutrients, such as vitamins and minerals (Sagar and Suresh Kumar, 2010). Extending post-harvest life of horticultural products, requires knowledge of all factors, that can cause loss of quality so as to develop affordable technologies, that Post-harvest losses of fresh fruits and vegetables, minimize the rate of deterioration. Length of storage, respiration, transpiration, chemical composition, external appearance, anatomical structures, delay harvesting, taste qualities and other post harvest behaviors, have significant impact on fruit quality. These controllable and uncontrollable factors, affect the attainment of maximum quality of fruits (Babalola et al., 2010). Dipping treatments, favor the dispersion of the solution on the surface of the vegetable (Soliva-Fortuny et al., 2003). Pre and post-harvest Calcium applications have been used, to delay aging or ripening, to reduce post-harvest decay and to control the development of many physiological disorders, in fruits and vegetables (Conway et al., 1994).

From the study of the effects of Calcium Chloride dip on the weight loss and texture of the carrot shreds, it is noted that, the treatment substantially maintained their quality, during the storage period. (Izumi and Watada, 1994). As ripening progressed in tomatoes, bound calcium content of control fruit decreased, in contrast, fruits treated with $8 \% \mathrm{CaCl}_{2}$ had increased, in the bound calcium content. It is also noted that, an increase in the concentration of Calcium Chloride increases the firmness of the fruit (Hong and Lee 1999). Post-harvest treatment of pineapples, with Calcium Chloride retards their decay rate (Goncalves et al., 2000). Calcium Chloride, Sodium Chloride and Lime juice were selected, in this study to treat Cucumbers. The aim of the present work was to determine the effects of these agents, on physico-chemical properties and to increase the shelf life of treated Cucumbers. 


\section{MATERIALS AND METHODS}

\section{Selection of Vegetables}

Fresh Cucumbers were procured from a local wholesaler, in Allahabad. All the Cucumbers were cleaned and sorted. The good ones were washed thoroughly with water.

\section{Preparation of Solutions and pre-Treatment}

Calcium Chloride, Sodium Chloride \& Lime juice each 3\% solutions were made from distilled water. The Selected Cucumbers were dipped in all the solutions, for 5 minutes and 10 minutes as per the experimental plan. After that, they were air dried under fan and kept in baskets at room temperature.

\section{Determination of $\mathbf{p H}$}

To determine the $\mathrm{pH}$, distilled water was taken in a beaker and the electrode of the $\mathrm{pH}$ meter was dipped in the distilled water, and reading of $\mathrm{pH}$ meter was set manually by knob to 7 i.e., the neutral value. Then, samples were taken in the beaker and $\mathrm{pH}$ was measured, by dipping electrodes of a digital $\mathrm{pH}$ meter.

\section{Determination of TSS}

TSS was measured using the Hand Refract meter. A drop of juice sample was dropped in the face of the Refract meter. TSS was noted through the eyepiece and is expressed as ${ }^{\circ}$ Brix.

\section{Determination of Weight Loss}

For determination of weight loss before storage, three fruits in each replication were separately marked and weighed on a digital balance, at the start of the experiment and thereafter, the same fruits were consistently weighed during the storage period. Weight was calculated by using the following formula:

Weight Loss $\%=$ (fruit initial weight-fruit weight at each sampling date/fruit initial weight) $\times 100$

\section{Determination of Shelf Life}

The data recorded during the course of the investigation were statistically analyzed, by the 'Analysis of varianceone way classification'. The significant effect of treatment was judged, with the help of ' $\mathrm{F}$ ' (variance ratio). Calculated $\mathrm{F}$ value was compared with the table value of $\mathrm{F}$ at $5 \%$ level of significance. If the calculated value exceeded the table value, the effect was considered to the significant. The significance of the study was tested $5 \%$ level, to study the differences in the processing parameter and premix in composition.

\section{Statistical Analysis}

After pre-treatment, the Cucumbers were drained, then the treated and control Cucumbers, were stored at room temperature. Shelf life was calculated by counting the number of days, the Cucumbers were acceptable for use by visual observation.

\section{RESULTS AND DISCUSSIONS}

Effect of Chemical \& Natural Agents on Physico-Chemical Properties

\section{PH of Cucumber}

The results regarding the $\mathrm{pH}$ of Cucumber are shown in Figure 3.1. As the storage period is increasing, the 
increase in $\mathrm{pH}$ of Control and Sodium Chloride and Lime juice treated Cucumbers were more, but the increase in $\mathrm{pH}$ of Calcium Chloride treated Cucumbers was less. On the 16th day, the $\mathrm{pH}$ of Calcium Chloride treated fruits, with steeping time of $5 \mathrm{~min}$ (5.61), $10 \mathrm{~min}$ (5.49) was less followed, by Sodium Chloride treated fruits with steeping time of $5 \mathrm{~min}$ (5.72), $10 \mathrm{~min}$ (5.62), compared to the Control (5.74) and Lime juice treated fruits with steeping time of 5 min (5.74), 10 $\min$ (5.72). On the 19th day, Control, Sodium Chloride treated Cucumbers with steeping time of $5 \mathrm{~min}$ and Lime juice treated Cucumbers were degraded. On the 22nd day, Sodium Chloride treated Cucumbers with steeping time of $10 \mathrm{~min}$ were spoiled, Calcium Chloride treated fruits with steeping time of 10 min were recorded, with a pH of 5.76, after $22^{\text {nd }}$ day they were spoiled.

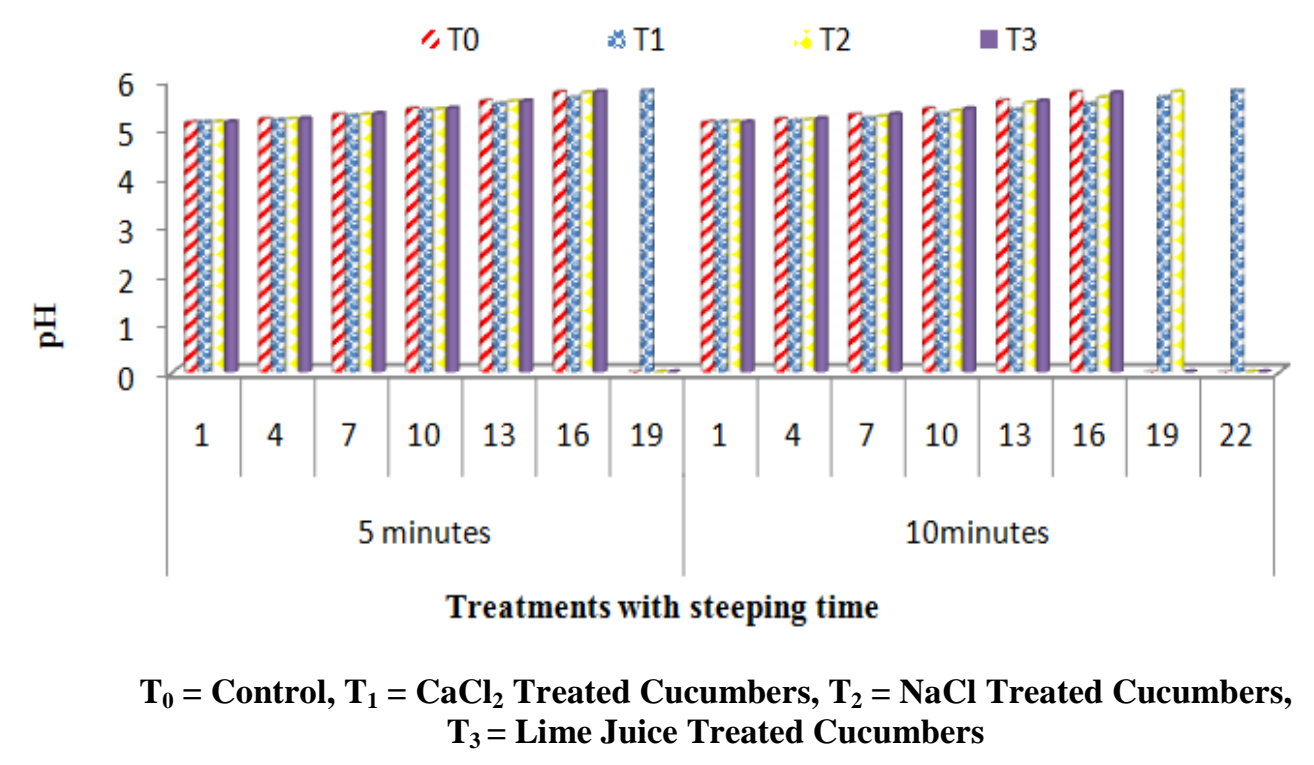

Figure 3.1: Effect of Calcium Chloride, Sodium Chloride and Lime Juice on pH of Cucumber

\section{TSS of Cucumber}

The results regarding to the TSS of Cucumber are shown in Figure 3.2. On $16^{\text {th }}$ day, the increase in TSS of Calcium Chloride treated Cucumbers with steeping time of $5 \mathrm{~min}\left(3^{\circ} \mathrm{Brix}\right), 10 \mathrm{~min}\left(2.7^{\circ} \mathrm{Brix}\right)$, was less followed by Sodium Chloride treated Cucumbers, with steeping time of $5 \mathrm{~min}\left(3.2^{\circ} \mathrm{Brix}\right), 10 \mathrm{~min}\left(3.1^{\circ} \mathrm{Brix}\right)$, compared to Control $\left(3.2^{\circ} \mathrm{Brix}\right)$ and Lime juice treated Cucumbers with steeping time of $5 \min \left(3.3^{\circ} \mathrm{Brix}\right), 10 \mathrm{~min}\left(3.4^{\circ} \mathrm{Brix}\right)$. On $19^{\text {th }}$ day, Control, Sodium Chloride treated Cucumbers with steeping time of $5 \mathrm{~min}$ and Lime juice treated Cucumbers were spoiled, Calcium Chloride treated Cucumbers with steeping time of $5 \mathrm{~min}$ and $10 \mathrm{~min}$, were recorded with a TSS of 3.4 ( $\left.{ }^{\circ} \mathrm{Brix}\right), 3.1$ ( ${ }^{\circ}$ Brix). On $22^{\text {nd }}$ day, Sodium Chloride treated Cucumbers with steeping time of 10 min were spoiled, Calcium Chloride treated Cucumbers with steeping time of 10 min was recorded, with a TSS of 3.7 ( $\left.{ }^{\circ} \mathrm{Brix}\right)$, after $22^{\text {nd }}$ day they were spoiled. 


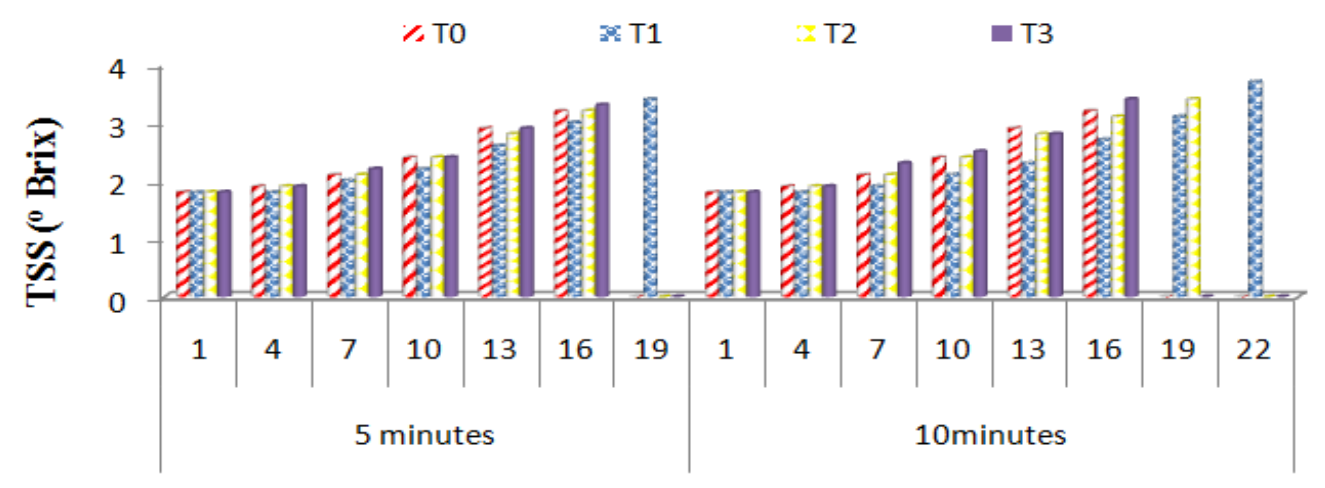

Treatments with steeping time

\section{$\mathbf{T}_{0}=$ Control, $\mathbf{T}_{1}=\mathrm{CaCl}_{2}$ treated Cucumbers, $\mathbf{T}_{2}=\mathrm{NaCl}$ treated Cucumbers, $\mathbf{T}_{3}=$ Lime juice treated Cucumbers}

Figure 3.2: Effect of Calcium Chloride, Sodium chloride and Lime Juice on TSS of Cucumber

\section{Weight Loss of Cucumber}

The results regarding to the weight loss of Cucumber is shown in Figure 3.3. As the storage period is increasing, the decrease in weight of Control and Sodium Chloride and Lime juice treated Cucumbers, was increased but the decrease in weight of Calcium Chloride treated Cucumbers was less. On $16^{\text {th }}$ day, the weight loss of Calcium Chloride treated Cucumbers with steeping time of $5 \mathrm{~min}(10.37 \%)$ and $10 \mathrm{~min}(10.01 \%)$, was less followed by Sodium Chloride treated Cucumbers with steeping time of $5 \mathrm{~min}(10.77 \%)$ and $10 \mathrm{~min}$ (10.64\%), compared to Control (10.85\%) and lime juice treated Cucumbers with steeping time of $5 \min (10.84 \%)$ and $10 \min (10.85 \%)$. On $19^{\text {th }}$ day Control, Sodium Chloride treated Cucumbers with steeping time of $5 \mathrm{~min}$ and Lime juice treated Cucumbers with steeping time of $5 \mathrm{~min}$ and $10 \mathrm{~min}$ were degraded. On $22^{\text {nd }}$ day, Sodium Chloride treated Cucumbers with steeping time of 10 min were spoiled, Calcium Chloride treated Cucumbers, with steeping time of 10 min were recorded with a weight loss of $16.82 \%$, after $22^{\text {nd }}$ day, they were spoiled.

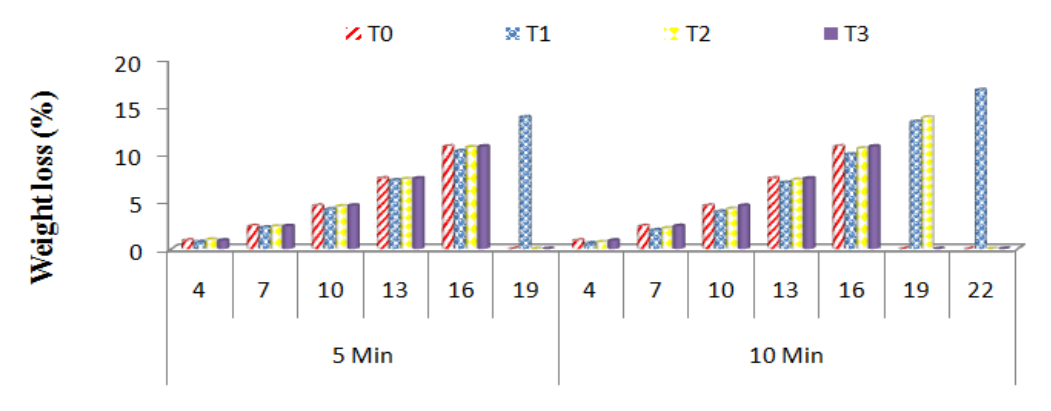

Treatments with steeping time

$\mathrm{T}_{0}=$ Control, $\mathrm{T}_{1}=\mathrm{CaCl}_{2}$ treated Cucumbers, $\mathrm{T}_{2}=\mathrm{NaCl}$ treated Cucumbers, $T_{3}=$ Lime juice treated Cucumbers

Figure 3.3: Effect of Calcium Chloride, Sodium Chloride and Limejuice on Weight Loss of Cucumber

\section{Shelf Life}

The results, regarding the shelf life of Cucumbers is shown in Figure 3.4. The shelf life of Calcium Chloride treated Cucumbers, with steeping time of 5 min (19 days) and 10 min (22 days) was more followed by Sodium Chloride 
treated Cucumbers, with steeping time of 5 min (16 days) and 10 min (16 days) compared to Control (16 days) and Lime juice treated Cucumbers, with steeping time of 5 min (16 days) and 10 min (16 days). There was increase in shelf life of fruits, treated with Calcium chloride, as calcium in the cell wall serves as a binding agent, which helps to maintain the quality and extend the storage life, particularly by delaying ripening and senescence, as well as reducing respiration rate and physiological disorder. The above results were comparative with Bhattara et al., (2006). There was no significant difference between Control and Lime juice treated Cucumbers.

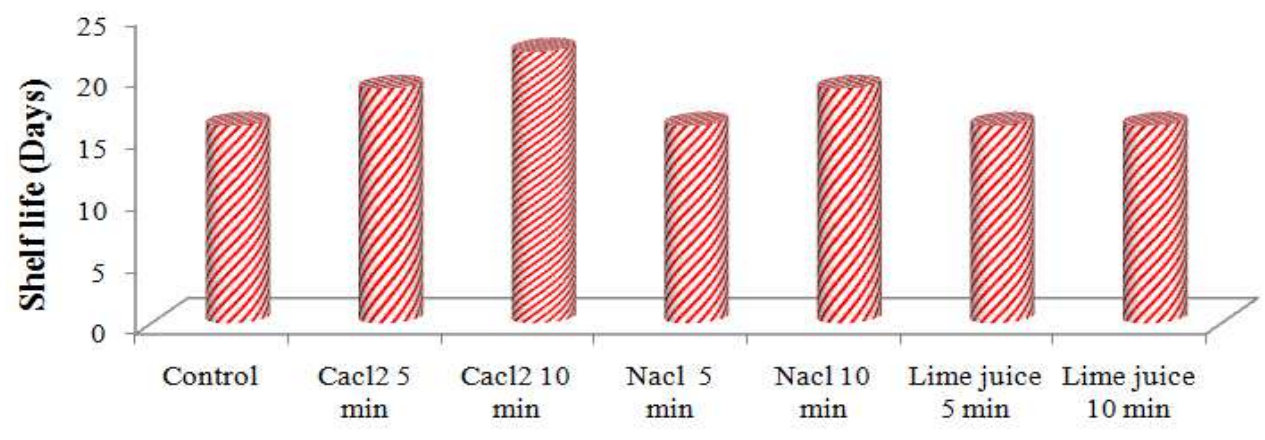

Treatments with steeping time

Figure 3.4: Effect of Calcium Chloride, Sodium Chloride and Lime Juice on Shelf Life of Cucumber

This investigation confirmed that, Calcium Chloride maintained the quality of treated Cucumbers under storage conditions. Pre and post-harvest calcium applications have been used, to delay aging or ripening, to reduce post-harvest decay, and to control the development of many physiological disorders, in fruits and vegetables (Conway et al., 1994). In our study, it was observed that, during storage $\mathrm{pH}$ of Cucumbers was increased, because acidity was reduced during storage growth on attainment of maturity and ripening (Upadhyay et al., 1994). Increase in $\mathrm{pH}$ of Calcium Chloride treated cucumbers was less, compared to control and other treatments. The results were compared with (Ferguson, 1984). The increase in $\mathrm{pH}$ might be due to the breakup of acids, with respiration during storage. The results are in agreement with the findings of Sabir et al., 2004. The increase in TSS of cucumbers, treated with Calcium Chloride was less, as the presence of $\mathrm{Ca} 2+$ ions increases the cohesion of cell-walls and delay fruit ripening (Demartyet al., 1984), Calcium Chloride delayed fruit ripening, improved resistance to fungal attack and maintained structural integrity of cell walls (Lara et al., 2004). The reduction in weight of cucumbers, treated with calcium chloride was less, but there was no significant difference between control and Lime juice treated cucumbers. Calcium applications have known to be effective in terms of membrane functionality and integrity maintenance, which may be the reason for the lower weight loss, found in Calcium Chloride treated Cucumbers (Lester \&Grusak 1999).

It is also noteworthy that, there was an increase in shelf life of Cucumbers, treated with Calcium chloride, as calcium might have delayed senescence and reduced the rate of respiration and transpiration, thus increased the shelf life (Mahajan \& Dhatt 2004).

\section{CONCLUSIONS}

This research reveals, variations in physico-chemical properties of Cucumbers, during storage. In terms of $\mathrm{pH}$, TSS and Shelf life, these work shows that, the effect of Calcium Chloride and Sodium Chloride on pre-treated Cucumbers is quite beneficial. The data also suggest that, the decrease in weight was less in Cucumbers treated with Calcium Chloride 
and Sodium Chloride. Overall, the results presented in this study show that, Calcium Chloride with steeping time of 5 min, 10 min and Sodium Chloride with steeping time of 10 min was effective, in increasing shelf life of fruits and vegetables. The results also suggest that, there was no effect of Lime juice on treating fruits and vegetables.

\section{REFERENCES}

1. Babalola, D. A.,Makinde, Y. O., Omonona, B. T., and Oyekanmi, M. O., 2010. Determinants of post harvest losses in tomato production: a case study of Imeko - Afon local government area of Ogun state. Journal of Life and Physical Sciences, Acta SATECH, 3 (2), 14-18.

2. Bhattarai, D. R. And Gautam, D. M. 2006. Effect of harvesting method and calcium on postharvest physiology of tomato. Nepal Agricultural Resource Journal. 7, 23-26.

3. Conway, W.S., C.E. Sams, C.Y. Wang, and J.A. Abbott, 1994. "Additive of the effects of postharvest calcium and heat treatments on reducing decay and maintaining quality in apples”, J. Am. Soc. Hortic. Sci., 119, 49-53.

4. Demarty, M., C. Morvan and M. Thellier. 1984. Ca and the cell wall. Plant Cell Environ., 7, 441- 448.

5. Goncalves, N.B., V.D. de Carvalho and J.R. de A. Goncalves, 2000. "Effect of calcium chloride and hot water treatment on enzyme activity and content oh phenolic compounds in pineapples”, Pesquisa Agropecuaria Brasileira, 35 (10), $2075-2081$ (Portuguesel English Abstract).

6. Hong, J. H., and S. K. Lee, 1999. “Effect of calcium treatment on tomato fruit ripening”, J. Korean Society of Horticultural Sciences, 40 (6), 638-642.

7. Izumi, H. and A.E. Watada, 1994.Calcium treatments affect storage quality of shredded carrots. Journal of Food Science, 59 (1), 106-109.

8. Lara, I., García, P., and Vendrell, M., 2004.Modifications in cell wall composition after cold storage of calcium-treated strawberry (Fragaria $\times$ ananassaDuch.) fruit. Postharvest Biology and Technology, 34 (3), 331-339.

9. Lester, G.E., Grusak, M.A., 1999.Postharvest application of calcium and magnesium to honeydew and netted muskmelons: Effects on tissue ion concentrations, quality, and senescence. J. Amer. Soc. Hort. Sci. 124, 545-552.

10. Mahajan, B.V.C. And A.S. Dhatt. (2004). Studies on postharvest calcium chloride application on storage behavior and quality of Asian pear during cold storage. Intl. J. Food, Agri. And Environment, 2 (3-4): 157-159

11. Sabir, MS, Shah SZA \&Afzal A (2004). Effect of chemical treatment, wax coating, oil dipping and different wrapping materials on Physio-chemical characteristics and storage behavior of apple (Malusdomestica Borkh). Pak J Nutrition 3 (2): $122-127$.

12. Sagar, V. R., \& Suresh Kumar, P. (2010). Recent advances in drying and dehydration of fruits and vegetables: A review. Journal of Food Science and Technology, 47:15-26.

13. Soliva-Fortuny, R. C., \& Martin-Belloso, O. (2003). New advances in extending the shelf life of fresh-cut fruits: a review. Trends in Food Science and Technology, 14: 341-353.

14. Upadhyay, I.P., A. Noomhorm, and S. G. Ilangantileke, (1994). "Effects of gamma irradiation and hot water treatment on the shelf life and quality of Thai mango cv Red," The Australian Centre for International Agricultural Research, pp. 348-351, 1994. 